\title{
Optimum Insulation Thickness for Walls and Roofs for Reducing Peak Cooling Loads in Residential Buildings in Lahore
}

\author{
SIBGHA SIDDIQUE*, SABAHAT ARIF*, AND ARIF KHAN* \\ RECEIVED ON 28.05.2015 ACCEPTED ON 16.09.2015
}

\begin{abstract}
Thermal insulation is the most effective energy saving measure for cooling in buildings. Therefore, the main subject of many engineering investigations is the selection and determination of the optimum insulation thickness. In the present study, the optimum insulation thickness on external walls and roofs is determined based on the peak cooling loads for an existing residential building in Lahore, Pakistan. Autodesk ${ }^{\circledR}$ Revit 2013 is used for the analysis of the building and determination of the peak cooling loads. The analysis shows that the optimum insulation thickness to reduce peak cooling loads up to $40.1 \%$ is 1 inch for external walls and roof respectively.
\end{abstract}

Key Words: Insulation, Energy Saving, Optimum Thickness, Residential, Cooling Loads.

\section{INTRODUCTION}

$\mathrm{E}$

nergy consumption is rapidly increasing due to ever increasing population, urbanization, migration to large cities and improvement in living standards. This is a serious fact that conventional energy sources i.e. fossil fuel are running out and the whole world is facing energy crisis. According to WAPDA (Water and Power Development Authority), it is getting even worse in Pakistan from last decade due to gap between supply and demand [1]. Pakistan needs approximately $20,000 \mathrm{MW} /$ day, out of which only $13,500 \mathrm{MW}$ is being produced and thus, there is a shortfall of $6500 \mathrm{MW}$ [2]. Under this scenario, there is a need to conserve energy.

Lahore is the second largest city in Pakistan with latitude $31.5^{\circ} \mathrm{N}$ and longitude $74.3^{\circ} \mathrm{E}$. The climate of Lahore is featured as composite climate, with rainy, long and extremely hot summer; foggy winter; dry autumn and pleasant spring. The typical daytime temperature in January is about $18^{\circ} \mathrm{C}$ and nighttime average temperature is $6^{\circ} \mathrm{C}$. While in the month of June, the average day time temperature exceeds $40^{\circ} \mathrm{C}$ and nighttime average temperature is $30^{\circ} \mathrm{C}$. Thus due to long sunny and hot climate, the major part of electric energy is used for cooling to achieve thermal comfort [3].

In Pakistan, buildings are the major sector of energy consumption and utilize about $76 \%$ of total electricity [4]. Therefore, a lot of energy would conserve by making these building energy efficient. The use of the insulation materials in external walls and roof is the direct and effective way to decrease the heat transfer

* Department of Architectural Engineering \& Design, University of Engineering \& Technology, Lahore.

Mehran University Research Journal of Engineering \& Technology, Volume 35, No. 4, October, 2016 [p-ISSN: 0254-7821, e-ISSN: 2413-7219] 
and electricity consumption [5]. However, it always leads to higher investment. Thus, the determination of the optimum thickness which could make the balance between the decreased energy consumption and increased investment of insulation layer is the scope of present work.

A wide range of organizations such as NREL (National Renewable Energy Laboratory) in USA, have examined the green building design and energy efficiency in buildings in different climates [6]. Bolatturk [7] studied the optimum thickness for walls with respect to cooling and heating degree hours in the warmest zone of Turkey and $\mathrm{Yu}$, et. al. [8], investigated on the optimal insulation thickness for the hot summer and cold winter zone of China where as Friess, et. al. [9], measured the wall insulation for the residential villas in Dubai.

In Pakistan, only a few studies are available related to the energy conservation through thermal insulation. Ahmad, et. al. [10], studied the effect of low cost roof insulating material on indoor temperature of building in Lahore. But none specifically examine the optimal thickness of insulation for buildings in Lahore.

\section{METHODOLOGY OF RESEARCH}

The objective of this work is to determine the optimum insulation thickness for wall and roof of residential buildings in Lahore on the basis of percentage reduction in peak cooling loads which is the key measure to conserve electricity. Peak cooling load is the amount of heat that must be removed over an hour's time to keep the space cool on the hottest day of summer. While designing the typical building air conditioning system, it must meet the peak cooling loads of building. With the increase in insulation thickness walls and roof, peak cooling load decreases and energy conservation increases. The other parameters which influence the optimal insulation thickness and used to make the quantitative comparison among the different insulation thicknesses are U-value and investment cost. U-value is the overall heat transfer coefficient, measures the effectiveness of a material in conducting heat and decrease with the increase in insulation thickness while investment cost is become quite higher with increasing thicknesses. A single family residential building is selected as case study. A virtual model of the case study building was created in Autodesk ${ }^{\circledR}$ Revit 2013 with necessary environmental data for simulation of cooling loads and determination of U-values and investment cost.

Autodesk ${ }^{\circledR}$ Revit 2013 is the BIM (Building Information Modeling) software which allows the user to design with completely integrated database with parametric drafting and modeling element. It contains the functionality of Revit Architecture, Revit MEP and Revit Structure in a single software application [11]. The environmental data for simulation in Revit includes the building construction data, glazing data, condition type, occupancy, sensible and latent heat gain values for electric loads, set point temperature and weather data. The construction, glazing, sensible and latent heat gain data is taken from ASHARE and CBISE standards. The condition type (heating only, cooling only or both), occupancy and set point temperature is defined according to the user requirements. The climatic data of Autodesk Revit comprises of annual weather data and design dry bulb temperature of each month. The values are taken from ASHRAE 2005 database of daily range and profile of dry-bulb temperature [12].

The building model is prepared in Revit Architecture and analysis is performed by Revit MEP. MEP is an intuitive mechanical, electrical and plumbing system design tool as well as integrated with building performance analysis tools to perform heating and cooling loads analysis, day lighting analysis and more to support sustainable design.

Mehran University Research Journal of Engineering \& Technology, Volume 35, No. 4, October, 2016 [p-ISSN: 0254-7821, e-ISSN: 2413-7219] 
The heating and cooling loads calculation in Revit MEP follows the ASHARE standards and based on the RTS (Radiant Time Series) method. This method follows the time delay effect as heat is transmitted into spaces from exterior and from the envelopes. The overview of RTS method is shown in Fig. 1.

The important areas of RTS method are computation of conductive heat gain, the splitting of all heat gains into radiant and convection portions and the conversion of heat gains into cooling loads. The conductive heat gain is calculated for each wall and roof type from Equation (1) by using 24 response factors which gives a time series solution to the transient, one dimensional conductive heat transfer problem.

$q_{\theta}=A \sum_{i=0}^{23} Y_{P j}\left(t_{e, \theta-j \delta}-t_{r c}\right)$ where $\mathrm{q}_{\dot{\mathrm{e}}}$ is hourly conductive heat gain, Btu/h $(\mathrm{W})$, for the surface, $A$ is surface area, $\mathrm{ft}^{2}\left(\mathrm{~m}^{2}\right), \mathrm{Y}_{\mathrm{Pj}}$ is $\mathrm{j}^{\text {th }}$ response factor, $\mathrm{t}_{\mathrm{e}, \mathrm{e}-\mathrm{j} a \mathrm{a}}$ is sol-air temperature, ${ }^{\circ} \mathrm{F}\left({ }^{\circ} \mathrm{C}\right)$, j hours ago, and $\mathrm{t}_{\mathrm{rc}}$ is presumed constant room air temperature, ${ }^{\circ} \mathrm{F}\left({ }^{\circ} \mathrm{C}\right)$.

The next step is simplifies the conductive heat gains by splitting into radiative and convective portions. The convective portion instantly contributes to cooling load while radiative portion is absorbed by the thermal mass in the zone and then convected into the space which creates a time lag and damping effect. Therefore, the radiant portion of hourly heat gain is converted into cooling loads from Equation (2) by using radiant time factors on the basis of current and past heat gain.

$Q_{\theta}=\sum_{n=0}^{23} r_{n} q_{\theta-n \delta}$

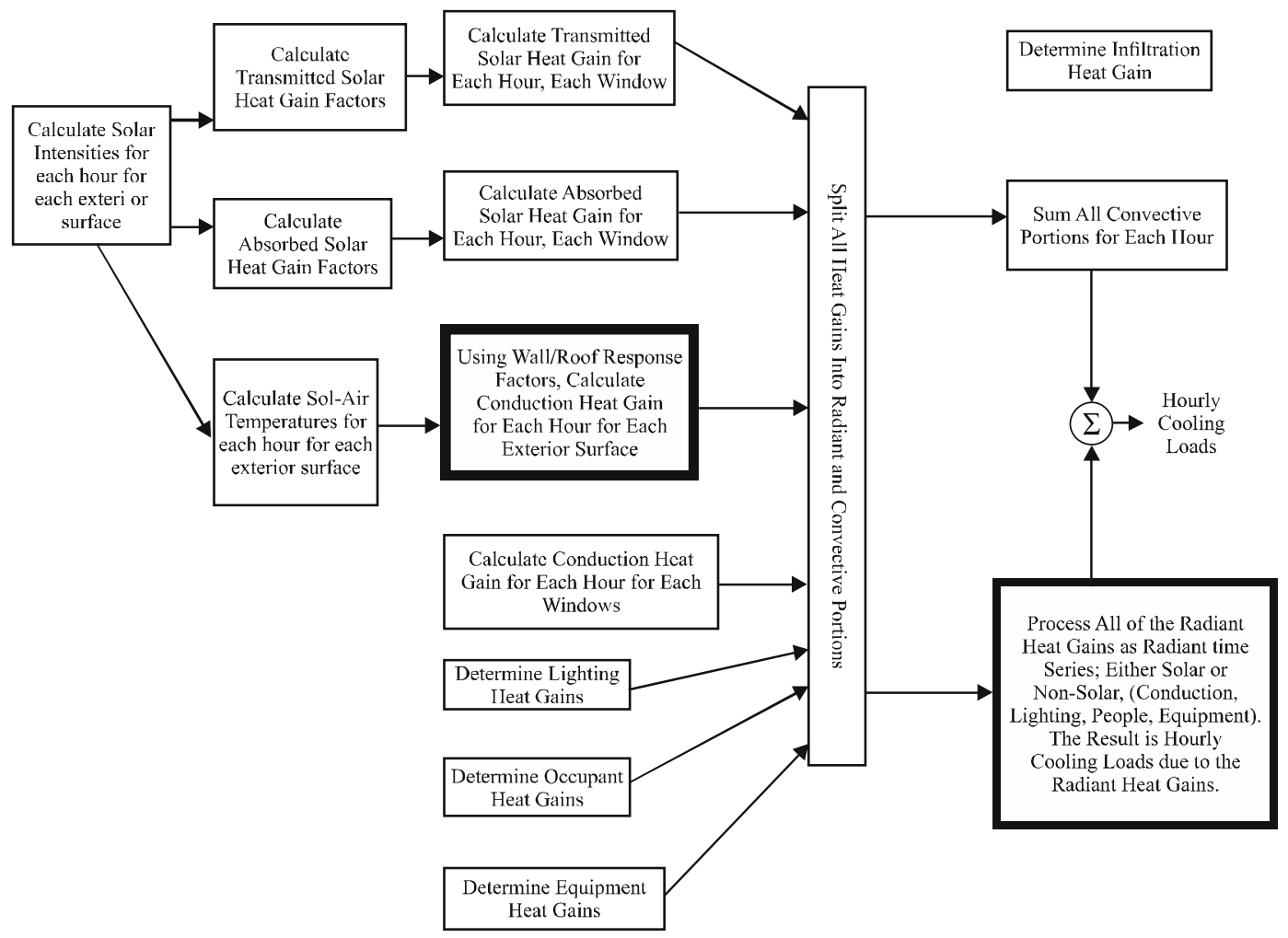

FIG. 1. OVERVIEW OF RADIANT TIME SERIES METHOD [13]

Mehran University Research Journal of Engineering \& Technology, Volume 35, No. 4, October, 2016 [p-ISSN: 0254-7821, e-ISSN: 2413-7219] 
Where $\mathrm{Q}_{\mathrm{e}}$ is Cooling load (Q) for the current hour (è), $\mathrm{Btu} / \mathrm{h}(\mathrm{W}), \mathrm{q}_{\mathrm{e}-\text { na }}$ is the radiant gain at $\mathrm{j}$ hours ago, Btu/h $(\mathrm{W})$, and $r_{n}$ is the $n$th time radiant factor, Btu/h $(\mathrm{W})$.

\subsection{The Base Case Building}

The case study building is located in T-Block, PhaseVIII, DHA Society, Lahore which served as base case. The selected building is recently constructed and representative of similar other residential buildings. It is a double storey single family residential building with covered area 2725 sq.ft (total area 4500 sq.ft). Its architectural planning as shown in Fig. 2(a-b), is fully compliance with the DHA bylaws. The orientation of the building is $39^{\circ} \mathrm{N}$. The design conditions are considered according to ASHRAE standards and building is simulated with conventional construction materials which described in Table 1.

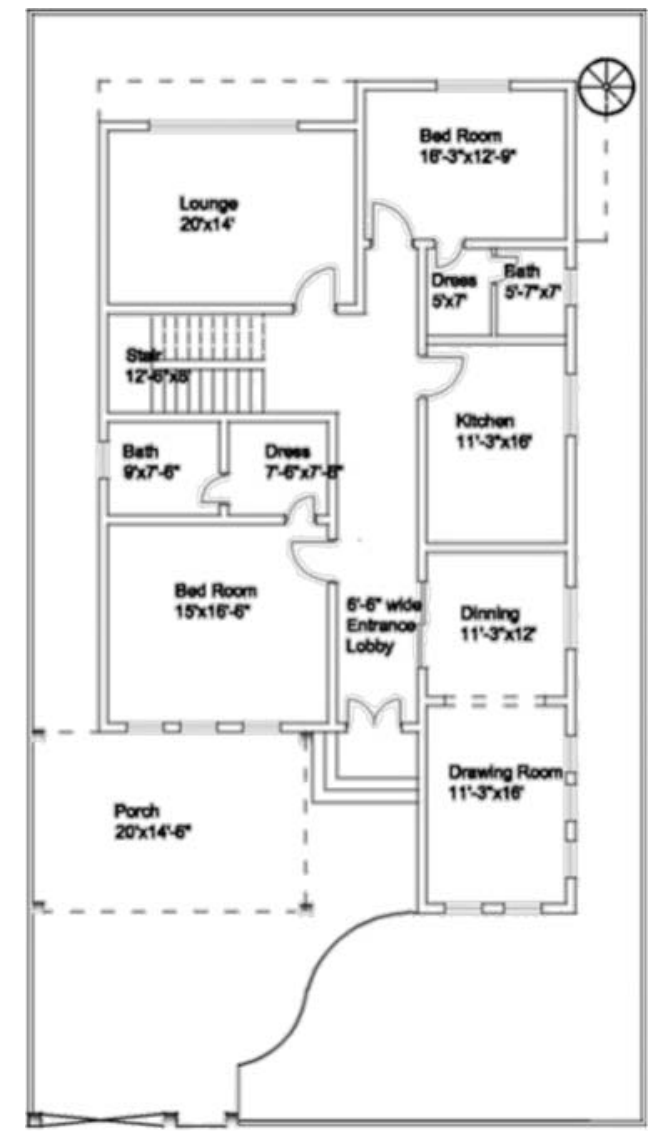

FIG. 2(a). ARCHITECTURAL PLAN (GROUND FLOOR)

\subsection{Modifications in Base Case}

The building walls and roof for the base case were modified by applying varying thicknesses of extruded polystyrene as insulation. Extruded polystyrene (XPS Diamond Jumbolon) is closed cell, locally available best insulation to reduce the thermal conductivity. It is more acceptable insulation than the other due to its high insulation performance, long term reliability, stable R-value, moisture resistance, strength and easy installation process without any special skills[14-15]. Only need is to place polythene sheets above the foam (extruded polystyrene) to protect from fresh concrete and water [16]. Its density is $32 \mathrm{~kg} / \mathrm{m}^{3}$ and thermal conductivity is $0.026 \mathrm{~W} / \mathrm{mK}$. Seven modifications to the walls and seven to the roof as shown in Table 2 were analyzed.

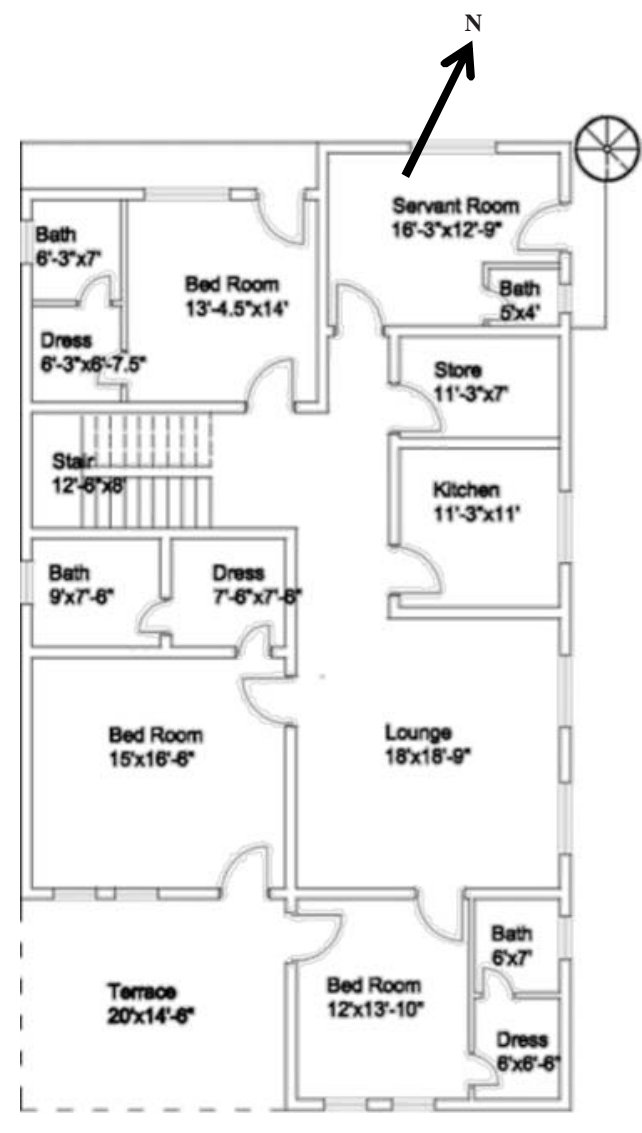

FIG. 2(b). ARCHITECTURAL PLAN (FIRST FLOOR)

Mehran University Research Journal of Engineering \& Technology, Volume 35, No. 4, October, 2016 [p-ISSN: 0254-7821, e-ISSN: 2413-7219] 


\subsubsection{Wall Modifications}

Walls are externally modified by adding the insulation with varying thicknesses ranging from $0.5,1,1.5,2,2.5$, 3,4. External insulation to wall involves plastering the brick work to provide a smooth surface, attachment of the insulation boards using cement adhesive and mechanical fixings, and inclusion of a fiber mesh in the final surface plastering and additional work to deal with openings and corners is required which needs more cost than roof i.e. $100 \mathrm{Rs} / \mathrm{ft}^{2}$ for 1 inch thickness.

\subsubsection{Roof Modifications}

The roof is modified by adding the insulation with varying thicknesses ranging from $0.5,1,1.5,2,2.5,3,4$ underneath the light weight concrete. The investment cost for roof insulation is $68 \mathrm{Rs} / \mathrm{ft}^{2}$ for 1 inch thickness. The mud phuska is retained in roof to prompt the consideration of mixing old and new techniques of insulation instead of totally replace the older techniques which are less expensive.

TABLE 1. BASE CASE BUILDING MODEL CHARACTERISTICS (AUTODESK REVIT LIBRARY DATA)

\begin{tabular}{|c|c|}
\hline Parameters and U-values & Characteristics of Model \\
\hline No of floors & 2 \\
\hline Floor Height & $12 \mathrm{ft}$. \\
\hline Total Area & 4500 sq.ft \\
\hline \multirow{5}{*}{ Ground Floor $(\mathrm{U}-$ Value $=1.330 \mathrm{~W} / \mathrm{m} 2 . \mathrm{K})$} & 0'-1/2" Ceramic Floor Tiles \\
\hline & 0'-2" Concrete \\
\hline & 0'-4" Brick Ballast \\
\hline & 0'-4" Sand \\
\hline & 0'-9" Earth \\
\hline \multirow{3}{*}{ Wall (U-Value= $1.880 \mathrm{~W} / \mathrm{m} 2 . \mathrm{K})$} & 0'-3/8" Plaster \\
\hline & 0'-9" Brick Masonry \\
\hline & 0'-3/8" Plaster \\
\hline \multirow{5}{*}{ Roof $(\mathrm{U}-$ Value $=1.290 \mathrm{~W} / \mathrm{m} 2 . \mathrm{K})$} & 0'-1 1/2" Roof Tile \\
\hline & 0'-2" Concrete Light Weight \\
\hline & 0'-3" Mud Phuska \\
\hline & 0'-3/8" Bitumen \\
\hline & 0'-6" Roof Slab Concrete (1:2:4) \\
\hline Glazing $(\mathrm{U}-$ Value $=5.440 \mathrm{~W} / \mathrm{m} 2 . \mathrm{K})$ & 0'-1/2" Glass Standard \\
\hline Model Thermal Zone & Bed Rooms, Lounge and Drawing Room on both floors \\
\hline Condition type & Cooling only \\
\hline Occupancy & 8 occupants \\
\hline Air infiltration rate & $0.5 \mathrm{ac} / \mathrm{hr}$ \\
\hline Sensible heat gain(per person) & $110 \mathrm{Btu} / \mathrm{hr}$ \\
\hline Latent heat gain(per person) & $185 \mathrm{Btu} / \mathrm{hr}$ \\
\hline Set point temperature & $260 \mathrm{C}$ \\
\hline
\end{tabular}

Mehran University Research Journal of Engineering \& Technology, Volume 35, No. 4, October, 2016 [p-ISSN: 0254-7821, e-ISSN: 2413-7219] 


\section{RESULTS AND DISCUSSION}

The base case and all the modifications were analyzed by Autodesk ${ }^{\circledR}$ Revit and their U-value, peak cooling loads, percentage difference with respect to base case and investment cost were calculated shown in Table 2.

It is clearly visible that increasing insulation has its primary effect in the summertime, when the gains through walls and roof are the largest and that the base case has higher peak cooling loads as compare to all other insulation modifications.

The results show that the insulation modifications in roof have significantly reduced the cooling load of the building as shown in Fig 3. The roof with $1 / 2$ inch and 1 inch insulation showing a decrease of 15.5 and $29.5 \%$ respectively in the peak cooling load compared to the base case. The roof with 1.5, 2 and 2.5 inches thicknesses show a decrease of $31.9,33.2$ and $33.8 \%$ respectively. The roof with 3 inch is depicting a decrease of $34.1 \%$. The roof with 4 inches thickness shows a decrease of $34.5 \%$.

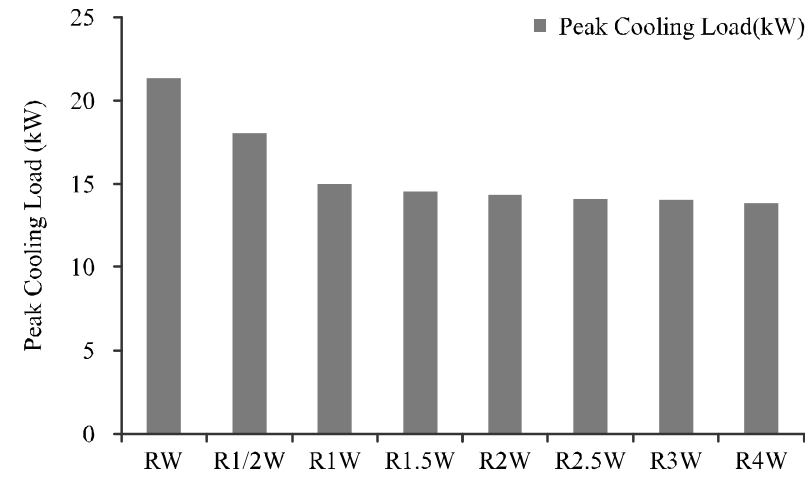

FIG. 3. COMPARISON OF PEAK COOLING LOADS BY MODIFICATIONS IN ROOF

TABLE 2. WALL AND ROOF MODIFICATIONS, THEIR PEAK COOLING LOADS, PERCENTAGE DIFFERENCE, INVESTMENT COST

\begin{tabular}{|c|c|c|c|c|c|}
\hline & Modifications & $\begin{array}{l}\text { U-value } \\
\left(\mathrm{W} / \mathrm{m}^{2} \cdot \mathrm{K}\right)\end{array}$ & $\begin{array}{c}\text { Peak Cooling } \\
\text { Load } \\
(\mathrm{kW}) \\
\end{array}$ & $\begin{array}{c}\text { Difference } \\
(\%)\end{array}$ & $\begin{array}{c}\text { Investment } \\
\text { Cost } \\
(\mathrm{PKR}) \\
\end{array}$ \\
\hline Base Case & RW - base case & - & 21.34 & - & - \\
\hline \multirow{7}{*}{ Roof Modifications } & $\mathrm{R} 1 / 2 \mathrm{~W}-$ base case +0.5 (in) XPS in roof & 0.88 & 18.032 & 15.5 & 93064 \\
\hline & $\mathrm{R} 1 \mathrm{~W}-$ base case +1 (in) XPS in roof & 0.580 & 15.002 & 29.5 & 147088 \\
\hline & $\mathrm{R} 1.5 \mathrm{~W}-$ base case $+1.5(\mathrm{in}) \mathrm{XPS}$ in roof & 0.48 & 14.554 & 31.9 & 201112 \\
\hline & $\mathrm{R} 2 \mathrm{~W}-$ base case +2 (in) XPS in roof & 0.38 & 14.34 & 33.2 & 255136 \\
\hline & $\mathrm{R} 2.5 \mathrm{~W}-$ base case +2.5 (in) XPS in roof & 0.33 & 14.106 & 33.8 & 309160 \\
\hline & $\mathrm{R} 3 \mathrm{~W}-$ base case +3 (in) XPS in roof & 0.28 & 14.042 & 34.1 & 363184 \\
\hline & R4W - base case +4 (in) XPS in roof & 0.22 & 13.871 & 34.5 & 471232 \\
\hline \multirow{7}{*}{ Wall Modifications } & $\mathrm{RW} 1 / 2$ - base case +0.5 (in) XPS in wall & 1.11 & 20.038 & 6.1 & 284160 \\
\hline & RW1 - base case +1 (in) XPS in wall & 0.670 & 19.163 & 10.2 & 390720 \\
\hline & RW1.5 - base case +1.5 (in) XPS in wall & 0.540 & 18.801 & 11.9 & 497280 \\
\hline & RW2 - base case +2 (in) XPS in wall & 0.410 & 18.608 & 12.8 & 603840 \\
\hline & RW2.5 - base case +2.5 (in) XPS in wall & 0.360 & 18.523 & 13.2 & 710400 \\
\hline & RW3 - base case +3 (in) XPS in wall & 0.3 & 18.48 & 13.4 & 816960 \\
\hline & RW4 - base case+ 4(in) XPS in wall & 0.230 & 18.416 & 13.7 & 1030080 \\
\hline
\end{tabular}

Mehran University Research Journal of Engineering \& Technology, Volume 35, No. 4, October, 2016 [p-ISSN: 0254-7821, e-ISSN: 2413-7219] 
The percentage difference of the peak cooling loads of roof insulation having different thicknesses from peak cooling load of base case is shown in Fig. 4. Thus the significant percentage difference of $29.7 \%$ of roof from base case is achieved with 1 inch insulation and only a $6 \%$ difference results with increase thickness from 1 inch to 4 inch. It shows that the incremental increase in insulation thickness progressively deliver the reducing benefits because insulation is provided to cut off heat gain and up to 1 inch thick insulation maximum heat gain is block and further increase in insulation thickness has no significant effect on ceasing the heat gain but the investment cost is increased too much and energy saving increases only $6 \%$. Thus the use of 1 inch insulation in roof is much economical.

The results show that insulation modifications in wall reduced the cooling load of the building as shown in Fig. 5. The wall with $1 / 2$ and 1 inch insulation showing a decrease of 6.1 and $10.2 \%$ respectively in the peak cooling load compared to the base case. The wall having 1.5, 2 and 2.5 inches thickness shows a decrease of 11.9, 12.8 and $13.2 \%$ respectively. The wall with 3 inches shows a decrease of $13.4 \%$ while the wall with 4 inches thickness results a decrease of $13.7 \%$.

The percentage difference of the peak cooling loads of wall insulation having different thicknesses from peak

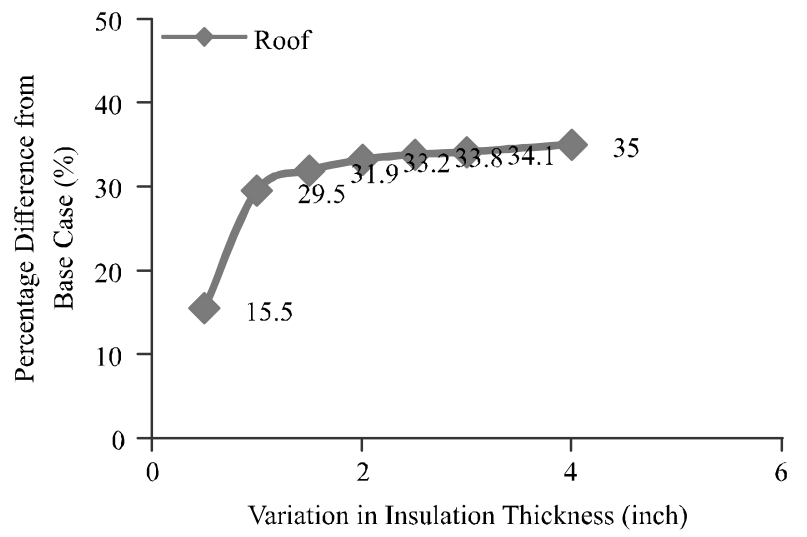

FIG. 4. PERCENTAGE DIFFERENCE OF ROOF INSULATION VARIATIONS FROM BASE CASE cooling load of base case is shown in Fig. 6. A significant percentage difference of $10.2 \%$ of wall with 1 inch insulation from base case is noted. Only a $4 \%$ of difference results with increasing the thickness from 1 to 4 inches. Using 4 inches insulation in wall will increase the cost of the building to much extent; however the use of 1 inch insulation in wall is much economical.

The Table 3 shows the simultaneously applied insulation modifications in roof and walls, their percentage difference from base case and investment cost of insulation. Since seven modifications to the walls and roof were formed and total 49 combinations for wall and roof insulation were analyzed.

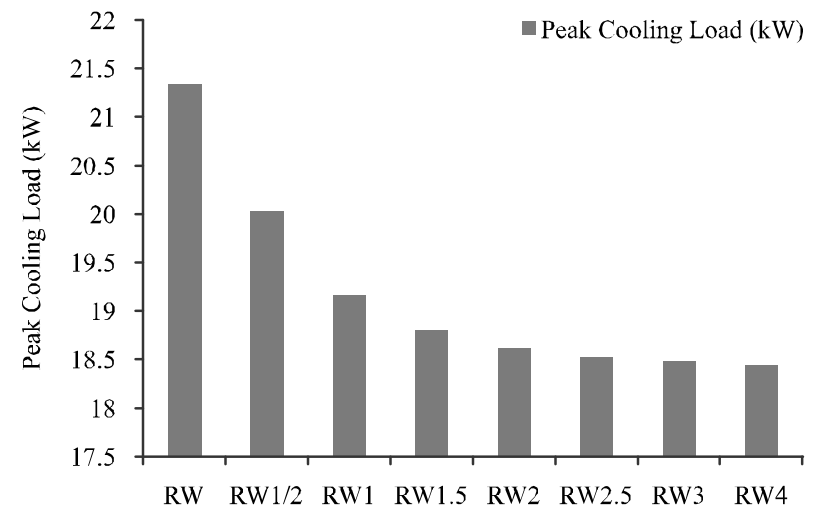

FIG. 5. COMPARISON OF PEAK COOLING LOADS BY MODIFICATIONS IN WALL

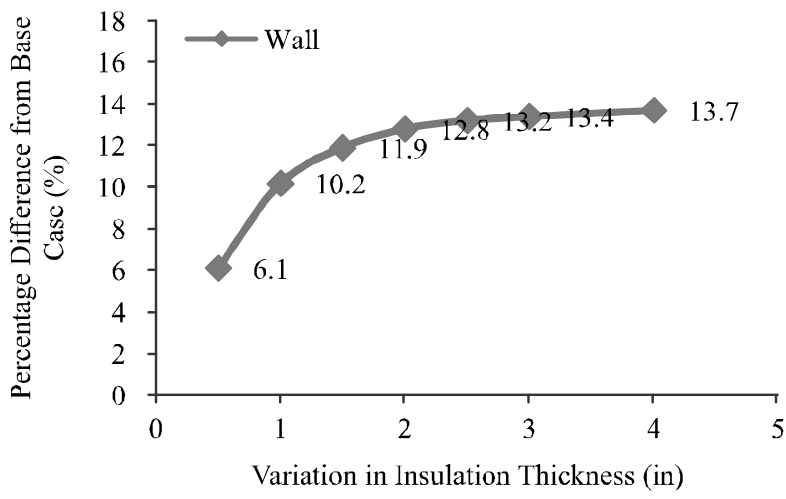

FIG. 6. PERCENTAGE DIFFERENCE OF WALL INSULATION VARIATIONS FROM BASE CASE

Mehran University Research Journal of Engineering \& Technology, Volume 35, No. 4, October, 2016 [p-ISSN: 0254-7821, e-ISSN: 2413-7219] 
TABLE 3. COMBINATIONS OF WALL AND ROOF INSULATION, THEIR PEAK COOLING LOADS, PERCENTAGE DIFFERENCE AND INVESTMENT COST

\begin{tabular}{|c|c|c|c|}
\hline Combinations of Wall and Roof Insulation & $\begin{array}{c}\text { Peak Cooling Load } \\
(\mathrm{kW})\end{array}$ & $\begin{array}{c}\text { Difference } \\
(\%)\end{array}$ & $\begin{array}{c}\text { Investment Cost } \\
\text { (PKR) }\end{array}$ \\
\hline $\mathrm{R} 1 / 2 \mathrm{~W} 1 / 2-$ base case $+0.5(\mathrm{in}) \mathrm{XPS}$ in roof +0.5 (in) XPS in wall & 16.795 & 21.3 & 377224 \\
\hline R1 W1/2 - base case+1(in) XPS in roof +0.5 (in) XPS in wall & 15.92 & 25.4 & 431248 \\
\hline R1.5 W1/2 - base case+1.5(in) XPS in roof+ 0.5 (in) XPS in wall & 15.514 & 27.3 & 485272 \\
\hline $\mathrm{R} 2 \mathrm{~W} 1 / 2-$ base case +2 (in) XPS in roof $+0.5($ in) XPS in wall & 15.301 & 28.3 & 539296 \\
\hline $\mathrm{R} 2.5 \mathrm{~W} 1 / 2$ - base case +2.5 (in) XPS in roof +0.5 (in) XPS in wall & 15.194 & 28.8 & 593320 \\
\hline R3 W1/2 - base case+3(in) XPS in roof+ 0.5(in) XPS in wall & 15.13 & 29.1 & 647344 \\
\hline R4 W1/2 - base case+4(in) XPS in roof +0.5 (in) XPS in wall & 15.066 & 29.4 & 755392 \\
\hline $\mathrm{R} 1 / 2 \mathrm{~W} 1$ - base case +0.5 (in) XPS in roof +1 (in) XPS in wall & 15.984 & 25.1 & 483784 \\
\hline R1W1 - base case+1(in) XPS in roof+ 1(in) XPS in wall & 12.783 & 40.1 & 537808 \\
\hline R1.5 W1 - base case+1.5(in) XPS in roof+ 1(in) XPS in wall & 12.527 & 41.3 & 591832 \\
\hline R2W1 - base case +2 (in) XPS in roof +1 (in) XPS in wall & 12.271 & 42.5 & 645856 \\
\hline R2.5 W1 - base case+1.5(in) XPS in roof+ 1(in) XPS in wall & 12.228 & 42.7 & 699880 \\
\hline R3W1 - base case+3(in) XPS in roof+ 1(in) XPS in wall & 12.121 & 43.2 & 753904 \\
\hline R4W1 - base case+4(in) XPS in roof +1 (in) XPS in wall & 12.036 & 43.6 & 861952 \\
\hline R1/2 W1.5 - base case +0.5 (in) XPS in roof +1.5 (in) XPS in wall & 13.786 & 35.4 & 590344 \\
\hline R1 W1.5 - base case+1(in) XPS in roof +1.5 (in) XPS in wall & 12.996 & 39.1 & 644368 \\
\hline R1.5 W1.5 - base case+1.5(in) XPS in roof+ 1.5 (in) XPS in wall & 12.612 & 40.9 & 698392 \\
\hline R2 W1.5 - base case+2(in) XPS in roof+ 1.5 (in) XPS in wall & 12.377 & 42 & 752416 \\
\hline R2.5 W1.5 - base case+2.5(in) XPS in roof+ 1.5 (in) XPS in wall & 12.313 & 42.3 & 806440 \\
\hline R3 W1.5 - base case+3(in) XPS in roof+ 1.5 (in) XPS in wall & 12.206 & 42.8 & 860464 \\
\hline R4 W1.5 - base case+4(in) XPS in roof +1.5 (in) XPS in wall & 12.185 & 42.9 & 968512 \\
\hline $\mathrm{R} 1 / 2 \mathrm{~W} 2$ - base case +0.5 (in) XPS in roof +2 (in) XPS in wall & 13.039 & 38.9 & 696904 \\
\hline R1W2 - base case+1(in) XPS in roof +2 (in) XPS in wall & 12.335 & 42.2 & 750928 \\
\hline R1.5 W2 - base case +0.5 (in) XPS in roof +2 (in) XPS in wall & 12.142 & 43.1 & 804952 \\
\hline R2W2 - base case+2(in) XPS in roof +2 (in) XPS in wall & 12.014 & 43.7 & 858976 \\
\hline R2.5 W2 - base case +2.5 (in) XPS in roof +2 (in) XPS in wall & 11.95 & 44 & 913000 \\
\hline R3W2 - base case+3(in) XPS in roof+ 2(in) XPS in wall & 11.929 & 44.1 & 967024 \\
\hline R4W2 - base case+4(in) XPS in roof + 2(in) XPS in wall & 11.609 & 45.6 & 1075072 \\
\hline R1/2 W2.5 - base case +0.5 (in) XPS in roof +2.5 (in) XPS in wall & 12.697 & 40.5 & 803464 \\
\hline R1 W2.5 - base case+1(in) XPS in roof+ 2.5 (in) XPS in wall & 11.929 & 44.1 & 857488 \\
\hline R1.5 W2.5 - base case+1.5(in) XPS in roof+ 2.5 (in) XPS in wall & 11.545 & 45.9 & 911512 \\
\hline R2 W2.5 - base case+2(in) XPS in roof+ 2.5 (in) XPS in wall & 11.417 & 46.5 & 965536 \\
\hline R2.5 W2.5 - base case +2.5 (in) XPS in roof + 2.5 (in) XPS in wall & 11.332 & 46.9 & 1019560 \\
\hline R3 W2.5 - base case+3(in) XPS in roof +2.5 (in) XPS in wall & 11.31 & 47 & 1073584 \\
\hline R4 W2.5 - base case +4 (in) XPS in roof +2.5 (in) XPS in wall & 11.268 & 47.2 & 1181632 \\
\hline $\mathrm{R} 1 / 2 \mathrm{~W} 3$ - base case +0.5 (in) XPS in roof +3 (in) XPS in wall & 12.783 & 40.1 & 910024 \\
\hline R1W3 - base case+1(in) XPS in roof+ 3(in) XPS in wall & 12.185 & 42.9 & 964048 \\
\hline R1.5 W3 - base case+1.5(in) XPS in roof +3 (in) XPS in wall & 11.929 & 44.1 & 1018072 \\
\hline R2W3 - base case+2(in) XPS in roof+ 3(in) XPS in wall & 11.78 & 44.8 & 1072096 \\
\hline R2.5 W3 - base case +2.5 (in) XPS in roof +3 (in) XPS in wall & 11.694 & 45.2 & 1126120 \\
\hline R3W3 - base case+3(in) XPS in roof+ 3(in) XPS in wall & 11.588 & 45.7 & 1180144 \\
\hline R4W3 - base case+4(in) XPS in roof +3 (in) XPS in wall & 11.502 & 46.1 & 1288192 \\
\hline $\mathrm{R} 1 / 2 \mathrm{~W} 4-$ base case +0.5 (in) XPS in roof +4 (in) XPS in wall & 12.569 & 41.1 & 1123144 \\
\hline R1W4 - base case+1(in) XPS in roof+ 4(in) XPS in wall & 12.121 & 43.2 & 1177168 \\
\hline R1.5 W4 - base case+1.5(in) XPS in roof +4 (in) XPS in wall & 11.822 & 44.6 & 1231192 \\
\hline R2W4 - base case+2(in) XPS in roof+ 4(in) XPS in wall & 11.588 & 45.7 & 1285216 \\
\hline R2.5 W4 - base case +2.5 (in) XPS in roof +4 (in) XPS in wall & 11.545 & 45.9 & 1339240 \\
\hline R3W4 - base case+3(in) XPS in roof + 4(in) XPS in wall & 11.438 & 46.4 & 1393264 \\
\hline R4W4 - base case+4(in) XPS in roof + 4(in) XPS in wall & 11.289 & 47.1 & 1501312 \\
\hline
\end{tabular}


It is clear that 4 inches insulation thickness in roof and 4 inches insulation thickness in wall (R4W4) shows the least peak cooling load. Only 1 inch insulation thickness in roof and 1 inch insulation thickness in wall advocates a significant peak cooling load difference from base case. The difference among the peak cooling loads of all other combinations with increase in insulation seems nonsignificant as shown in Fig. 7. It is inferred that for economical solution modification with 1 inch insulation thickness in roof and 1 inch insulation thickness in wall (R1W1) should be used.

\section{CONCLUSIONS}

The present study has analyzed the thermal performance of a single-family double storey residential building in Lahore to determine the optimum insulation thickness for building roof and walls based on peak cooling loads. The envelope with 4 inches insulation thickness in roof and 4 inches thickness in walls shows the least peak cooling loads reduction of $47.1 \%$ from base case. The construction cost increases with the thickness of insulation and hence, increases the overall cost of the building.

For the cost effective construction, the external wall having 1 inch external layer of extruded polystyrene and the 1 inch insulation layer in roof is considered as optimum insulation thickness for energy efficient and cost effective construction, which show nearly the same results i.e. peak cooling loads reduction of $40.1 \%$, but its construction is cheaper. So this modification can be considered for cost effectiveness.

For cost effective energy efficient envelope construction, it is concluded that the effect of insulation on roof is much significant as compared with the effect of insulation on walls. Therefore in some cases to make cost effective construction the insulation can be applied to roof only which would also give a significant decrease in peak cooling loads.

\section{FUTURE WORK}

The whole building life cost and projected energy cost savings data will be incorporated in future study to enhance the assessment of optimum insulation and calculation of payback period.

\section{ACKNOWLEDGEMENT}

The authors are grateful to the Directorate of Research, University of Engineering \& Technology, Lahore, Pakistan, for support and encouragement.

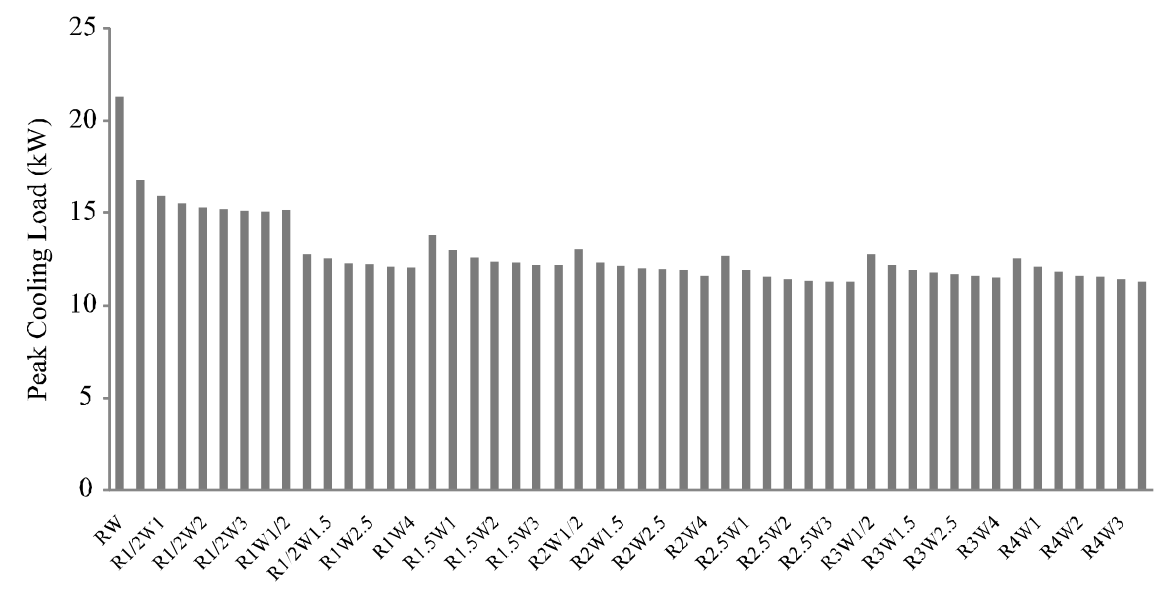

FIG. 7. COMPARISON OF PEAK COOLING LOADS BY MODIFICATIONS IN BOTH WALL AND ROOF

Mehran University Research Journal of Engineering \& Technology, Volume 35, No. 4, October, 2016 [p-ISSN: 0254-7821, e-ISSN: 2413-7219] 


\section{REFERENCES}

[1]

Saeed, F., Ahmad, S.T., and Butt, A.Q., "Simulation of Electricity Consumption for Newly Built Residential Buildings in Lahore", Journal of Research in Architecture and Planning, Volume 14, No. 1, pp. 55-60, Pakistan, March, 2013.
Javaid, M.A., Hussain, S., Maqsood, A., Arshad, Z., Arshad, M.A., and Idrees, M., "Electrical Energy Crisi in Pakistan and Their Possible Solutions", International Journal of Basic and Applied Sciences, Volume 11, No. 5, pp. 2635, Pakistan, October, 2011.

Sajjad, S.H., Batool, R., Qadri, S.M.T., Shirazi, S.A., and Shakrullah, K., "The Long-Term Variability in Minimum and Maximum Temperature Trends and Heat Island of Lahore City, Pakistan”, Science International, Volume 27, No. 2, pp. 1321-1325, Pakistan, March, 2015.

Arif, S., Khan, A., and Alamgir, K., "Environmental Issues and Energy Conservation in Buildings in Pakistan: Role of Architectural Intervention”, The Nucleus, Volume

No. 2, pp. 137-142, Pakistan, March, 2011.

Zhu, P., Huckemann, V., and Fisch, M.N., "Optimum Thickness and Enegy Saving Potential of External Wall Insulation in Different Climatic Zones of China", Procedia Engineering, Volume 21, No. 1, pp. 608-616, Germany, September, 2011.

Torcellini, P., Pless, S., Deru, M., Griffith, B., Long, N., and Judkoff, R., "Lessons Learned from Case Studies of Six High-Performance Buildings", NREL/TP-55037542, pp. 1-151, United States of America, June, 2006.

Bolatturk, A., "Optimum Insulation Thickness for Building Walls with respect to Cooling and Heating Degree-Hours in the Warmest Zone of Turkey", Building and Environment, Volume 43, No. 1, pp. 1055-1064, Turkey, February, 2008.

Yu, J., Yang, C., Tian, L., and Liao, A., “A Study on Optimum Insulation Thickness of External Walls in Hot Summer and Cold Winter Zones of China", Applied Energy, Volume 86, No. 1, pp. 2520-2529, China, April, 2009.
[9] Friess, W.A., Rakhshan, K., Hendawi, T.A., and Tajerzadeh, S., "Wall Insulation Measures for Residential Villas in Dubai: A Case Study in Energy Efficiency", Energy and Buildings, Volume 44, No. 1, pp. 26-32, United Arab Emirates, April, 2012.

[10] Ahmad, K., Arif, S., Khan, A., and Mushtaq, M., "Effect of Low Cost Roof Insulating Materials on Indoor Temperature of Buildings in Lahore", Pakistan Journal of Science, Volume 65, No. 2, pp. 239-242, Pakistan, June, 2013.

[11] Wong, K.D., and Fan, Q., "Building Information Modeling (BIM) for Sustainable Building Design", Facilities, Volume 31, No. 3, pp. 138-157, China, September, 2013.

[12] Bahar, Y.N., Pere, C., Landrieu, J., and Nicolle, C., "A Thermal Simulation Tool for Building and its Interoperability through the Building Information Modeling (BIM) Platform”, Buildings, Volume 3, No. 2, pp. 380-398, France, May, 2013.

[13] Spitler, J.D., Fisher, D.E., and Pedersen, C.O., "The Radiant Time Series Cooling Load Calculation Procedure", ASHARE Transactions, Volume 103, No 2, pp. 503-515, USA, July, 1997.

[14] Al-Houmoud, M.S., "Performance Characteristics and Practical Applications of Common Building Thermal Insulation Materials", Building and Environment, Volume 40, No 3, pp. 353-366, Saudi Arabia, March, 2005.

[15] Fabian, B., Herrenbruck, S., Hoffee, A., "The Environmental and Social Values of Extruded Polystyrene Foam Insulation”, Eath Tech Forum 200, pp. 1-16, USA, April, 2004.

[16] Un-Habitat, "Energy Efficient Housing: Improvement of Thermal Performance of RC Slab Roofs", UNHABITAT Pakistan, pp. 1-69, Pakistan, November, 2010. 